LETTER

\section{Paradox of success and public perspective: COVID-19 and the perennial problem of prevention}

Early in the COVID-19 pandemic, some were speculating that, if social distancing worked, growth (spread) slowed and hospital capacity was not exceeded (all of which were purposes of imposing the restrictions), then people would start saying that precautions were unnecessary, and demand a quick return to 'normal'.

That appears to be where we are now. The flattening of the disease curve and the reduction from the predicted number of deaths in many areas are the results of the actions taken to reduce spread. However, that does not mean that the pandemic is over, nor does it mean that it is time to eliminate the protective measures we have taken. The slowdown is evidence that the social distancing tools are working as intended. Deciding to return to normal and cease most social distancing restrictions is similar to a familiar clinical problem in which a patient stops antibiotics 2 days into a course of treatment, because the drugs are working, and the patient feels better, often with a bad outcome. Nevertheless, in the current pandemic, even some clinicians and hospital administrators are subject to this rush back to 'normality', perhaps in part because a 'stay-at-home' policy is a threat to revenue streams from elective procedures and laboratory procedures upon which clinicians and hospitals depend for economic viability.

A tendency to discontinue preventive measures that are working is a familiar problem in public health. The more successful a prevention programme, the more quickly public opinion comes to trivialise the severity of the original problem, and to view prevention as unnecessary and wasteful. The anti-vaccination movement is one manifestation of this dilemma. Few American adults today remember seeing children dying of measles or pertussis, which have become exceedingly rare. People fail to see the need to vaccinate because the risk of contracting these diseases is perceived as low. However, these diseases are rare as a direct result of vaccination and the resulting herd immunity.

It is up to medical and public health professionals, including clinicians, epidemiologists, biostatisticians, infectious disease researchers, etc., to educate those around us as to the importance of effective preventive practices and to not allow withdrawal as a response to evidence supporting their success. It is difficult to see statements on social media and other platforms that completely disagree with our training, knowledge and experience. We may feel reluctant to engage in discussion in order to avoid confrontation and dialogue that our friends, family and others in the community find argumentative and dismissive of their beliefs and/or needs. However, we have a responsibility to correct misstated facts and counter misleading information. This is the time for health professionals to correctly inform those who see these communications, our public posts and our responses to other posts. Even if we do not change individual opinions, we can expose readers to correct information and hope that it will make a difference. It is our professional responsibility to try to assure that decisions to change preventive policy are driven by science and data.
Shari Messinger Cayetano (iD) ${ }^{1,2}$ Lee Crandall ${ }^{3}$

'Public Health Sciences, University of Miami Miller School of Medicine, Miami, Florida, USA

2University of Miami

${ }^{3}$ Public Health Sciences, Clemson University, Clemson, South Carolina, USA

Correspondence to Shari Messinger Cayetano, Department of Public Health Sciences, University of Miami Miller School of Medicine, Miami, FL 33136 1015, USA; smessinger@biostat.med.miami.edu

Contributors SMC and LC contributed to the writing of this article and have equal contributions.

Competing interests None declared.

Patient consent for publication Not required.

Provenance and peer review Not commissioned; internally peer reviewed.

\section{0 \\ OPEN ACCESS}

Open access This is an open access article distributed in accordance with the Creative Commons Attribution Non Commercial (CC BY-NC 4.0) license, which permits others to distribute, remix, adapt, build upon this work non-commercially, and license their derivative works on different terms, provided the original work is properly cited, appropriate credit is given, any changes made indicated, and the use is noncommercial. See: http://creativecommons.org/licenses/ by-nc/4.0/.

(C) Author(s) (or their employer(s)) 2020. Re-use permitted under CC BY-NC. No commercial re-use. See rights and permissions. Published by BMJ.

\section{Check for updates}

To cite Messinger Cayetano S, Crandall L. J Epidemiol Community Health 2020;74:679.

Received 8 May 2020

Accepted 22 May 2020

J Epidemiol Community Health 2020;74:679. doi:10.1136/jech-2020-214518

ORCID iD

Shari Messinger Cayetano http://orcid.org/0000-0003$1182-2280$ 